\title{
EMBODIED URBANISMS: Corruption and the Ecologies of Eating and Excreting in India's Real Estate Economies
}

\section{NAMITA VIJAY DHARIA \\ Rhode Island School of Design}

(iD https:/ / orcid.org/0000-0002-7888-5094

Sewage surges through the main canal in Virgaon village, a small hamlet on the outskirts of the city of Gurgaon, India. Toxic green suds pop at the surface of the canal's black waters and unidentifiable clumps of gray matter pool into the plastic bags that float along the nala (canal/sewer/drain). The fetid waters and the garbage heaps that mark the nala's banks make all those who walk along it wrinkle and cover their noses in distaste. The warm and somehow alluring smell of raw sewage spreads during a quick downpour as the nala exceeds its boundaries and floats gently onto Virgaon's unpaved roads, leaving behind a layer of slime as the water recedes. The slime squelches into the open-toed rubber sandals of Virgaon's residents as they walk across the transforming ruro-urban streets.

The presence of excess sewage in Gurgaon is a result of its rapid urban development. As the apotheosis of matter out of place, sewage indexes a growing urban region but also reeks of corruption and contamination. In this article I explore how corruption, as a physical and political-economic phenomenon, manifests embodied criticisms and anxieties around social relations and urban development in Gurgaon (now known as Gurugram). I highlight the metabolic connections between body and environment to argue that discourses and sensoriums of sewage, food, and bodily behavior allow corruption to be understood in embodied ways; ${ }^{1}$ 
together, these discourses present critiques of caste-class inequity and mobility in real estate and construction economies in Gurgaon.

Corruption talk in Gurgaon situates itself in conversations of embodied urban ecologies (e.g., Chen 2012; Agard-Jones 2013; Zhang 2020): it links the metabolic systems of the body (e.g., Watanabe 2015; Solomon 2016) to the metabolic systems of urban infrastructures and ecologies (e.g., Swyngedouw 2006; Rademacher and Sivaramakrishnan 2013) to highlight the coproduction of built environment and embodiment in real estate economies. ${ }^{2}$ Corruption talk deploys aspects of urban metabolisms to speak of the economy as corrupting both the body and the urban region; these aspects express how waste and value are mediated through embodiment, and serve to express localized conceptions of the urban metabolic rift. ${ }^{3}$

Two understandings of corruption in India - political-economic or financial corruption and caste-based interpretations of corruption - are brought together in this article as a reminder that embodiment makes for a critical site of the formation and critique of urban development. Corruption is an elusive concept (Pardo 2018, S61). As a political-economic phenomenon, it is understood as a blurring of boundaries, most often between state officials' public and private activities, and presents itself in relationship to the state (Herzfeld 1992; Gupta 2012), but this blurring also allows it to construct relationships across categories otherwise understood as unconnected, such as body and real estate. Linked to ideas of financial gain, corruption is fundamental to real estate economies. Corruption discourse often assumes a corrupt male subject, giving it a masculine register and making it revealing of patriarchal logics (Aradhana Sharma 2018, S72-73). Because it is closely associated with dirt or dirtiness (Smart 2018, S40), corruption can be critiqued through bodily and scatological humor (Mbembe 1992). ${ }^{4}$

Political-economic corruption's embodied connections are heightened in the Indian context due to caste-based readings of contamination, ${ }^{5}$ where dominant castes view impurity as produced through the handling of waste and other substances (including garbage, meat, and leather), residing within the fluids of nondominant-caste individuals (e.g., Valmiki 2003), and even inscribed into space (e.g., Lee 2017). Physical corruption therefore plays a significant role in how real estate in India's National Capital Region comes to be read. Historical caste-based oppression, ${ }^{6}$ in which impurity is attached to the politics of waste, ingestion, and bodily fluids, allows economic corruption in India to be understood as embodied and sensory.

Here I make a connection between the Hindi root of bhrash (to fall), seen in brashtachaar (political-economic corruption) and dharma bhrasta (to fall from one's 
religion through violation of caste norms, e.g., by eating meat or traveling across the dark waters). According to dominant Hindu philosophy, dharma falls on exposure to impure or inauspicious elements, but impurity can also result from a disturbance of humoral balances (Raheja 1988, 48-49). The idea of falling from a high position because of an impurity is thus also embedded in the idea of political-economic corruption through the word bhrashtachaar, or, literally, "fallen practice." Ill-gotten economic wealth, excreta, and physio-ecological imbalances have caste connotations, categorized under the category of impurity. I use the terms dominant caste and non-dominant caste in accordance with Suraj Yengde's (2019, chapter 1) call to reject the "upper-lower signifiers of caste" because they are "downward-looking hierarchical terms," and instead refer to castes such as Brahmins and Baniyas as dominant. This usage differs from M. N. Srinivas's $(1959,2)$ use of dominant-caste, where the term represents a caste that is numerically strong in a village (such as Ahirs or Jats) but does not occupy a high ritual rank. I examine discourses surrounding the body (often imagined as male), narrated to a dominant-caste, female ethnographer doing fieldwork in a male-dominated industry. This encounter reveals the powers and anxieties of patriarchal and dominant-caste worlds. Local corruption discourse links metabolic understandings of body and environment to present a changing real estate economy as both desirable and dangerous.

Gurgaon, a city adjacent to New Delhi, falls within the National Capital Region (NCR), and for the past three decades it has witnessed unprecedented urban growth. The footprint of the urban region grew by the size of twelve Manhattans in the six years between 2007 and 2012. The urban area expanded through privatized real estate development in the late 1990s, as the site of a Business Process Outsourcing (BPO) center as well as the headquarters of multinational firms in India. Nearby New Delhi's real estate restrictions allowed real estate speculation to become a primary economy in Gurgaon, ${ }^{8}$ and it led to land becoming a central source of capital in the region (Denis and Zérah 2017, 9).

In 2012, when I moved to the National Capital Region to conduct dissertation fieldwork, I found myself confronted with anti-corruption protests. ${ }^{9}$ Gossip and rumor about political corruption accompanied me as I met with individuals in the construction industry - engineers, investment bankers, developers, landowners, foremen, architects, craftsmen, and helpers. The small- and large-scale construction sites, as well as farmhouses and developer offices in which I spent time, allowed many an individual to give me their opinion on the ongoing protests. As an architect trained in Mumbai at the height of its real estate mafia wars, 
and as a child of a landscape architect, I had some knowledge of the ubiquity of bribing practices across the production chain, the collusion between politicians and developers, and the laundering of cash reserves in real estate. But corruption talk in Gurgaon made me realize that these practices proved fundamental to the operations of real estate. Further, farming and migrant communities in Gurgaon draw connections between physical and political-economic corruption in relation to the transforming ruro-urban landscape. The body of the self and the body of the imagined other emerge as crucial sites of caste-class struggle in real estate as critiques of accumulation and practices of discrimination are deployed to challenge and support real estate economies. The rise of visual, descriptive, olfactory, and material constructions of corruption and metabolism in Gurgaon-smelling corruption in sewage, seeing it in the weight of the belly, or feeling it in rising desire - demonstrates how the labor, economies, and infrastructures of changing urban ecologies are understood and critiqued.

\section{CONTAMINATIONS}

"When money came to us, we were not prepared." Mr. Yadav, a former village panchayat (governing council) head and Ahir community member, is talking to me about urban development in the region. Ahirs, often recognized by the last name Yadav, are a caste classified as socially or educationally disadvantaged in the state of Haryana (in the government's terminology, "Backward Classes"), ${ }^{10}$ but several members have grown wealthy through landholdings in Gurgaon; Mr. Yadav talks of his community's experience.

It is 8 a.m. and the sun is still low in the sky: sunbeams streak across the tilled vegetable garden on my left, as young saplings peek out of the deep furrows of the alluvial soil. The saplings are framed by an opulent, baroque-style bungalow painted gold and pink; together, they mark the aesthetic admixtures of the transforming urban villages of Gurgaon. The mirrored facades of Cyber City — Gurgaon's multinational office hub_-shine in brilliant blues and greens on the horizon, reminding us that this plot sits amid a booming real estate market.

It is 2012 and Gurgaon has emerged as the poster child and petri dish of rapid land financialization and privatized real estate development. Residential property tripled and quadrupled in a seven- or eight-year span, ${ }^{11}$ and the National Capital Region came to be the fastest-growing region in the world (USGS 2016). Mr. Yadav and I find ourselves in the midst of a gold rush - the land economy is so heightened that all forms of elites, including corporate, professional, and state 
actors, are involving themselves with land speculation and prospecting (Goldman 2011).

Yet all is not luminescent in Gurgaon: technocrats hold the city up as an example of what to avoid in urban development (Kumar and Misra 2012). Largescale privatized real estate growth, unchecked by state officials and aided by public-private collusion, saw an urban area emerge without adequate infrastructure in what was once forest and farmland. While water supply and electricity needs were met through tube wells and diesel generators, the immediate urban problem was sewage and garbage. Sewage overflowed into water canals and streets as septic tanks clogged and drainage systems proved woefully inadequate. The urban villages of Gurgaon — such as Virgaon - bore the acute repercussions of this fastpaced growth as they turned into spaces of bureaucratic neglect.

Mr. Yadav, in his muddy pajamas, seems far away from this development drama. A handsome old man with twinkling eyes, Mr. Yadav is dressed in Haryanavi village garb_-kurtas, pajamas, and a checked scarf wrapped around his head-and carries dry straw (chaara) to the cows tethered next to us. He makes soft clicking noises of affection as he pets the grazing creatures, and a strong smell of cow dung permeates the air. He explains Gurgaon's largest development trouble (as articulated by state officials): "Gurgaon has a sewerage problem." This, he feels, has occurred because developers do not care about what goes on outside their compound walls. "You know how the development of Gurgaon is; if you develop one lane, then you do not think about what happens in the next lane." When people originally settled in Mr. Yadav's village, he says, they would not have imagined a scenario like today's. "Our village does not have a sewerage system. Things are up somewhere and down somewhere. We cannot bring it into rhythm.”

Turn a corner from Cyber City and you will find proof of this arrhythmia in Javgad village's arterial road. The main entrance to the village is just a short walk from the tall palaces of multinational capital. The main road is a nala of its own. Blackened sewage fills the furrows cast by truck tires moving along the muddy surface of the unpaved road. The black, garbage-filled waters form a shallow pool, its reflective surface concealing what lies beneath. Visiting a school in Javgad, I reluctantly hike up my pants and walk into the waters of human waste, cognizant that this is likely what most of the children do to get to school. The glorious glass towers of multinational India reflect in the blackened pool and ripple surreally as I slosh through the waste products of real estate speculation.

Dominant-caste Hindus have a fear of bodies and fluids and strong ritual protocols exist to manage them: ${ }^{12}$ to be contaminated by the spit, blood, or 
excreta of a non-dominant-caste individual means to be rendered impure. As a spiritual guru reminded me, his kitchen could be rendered impure by the wrong person touching his cooking vessels. "I am a very vehmi [superstitious] man," he claimed; "I do not to let just anybody into my kitchen." Food, for the guru, can be corrupted by the wrong person's presence in the kitchen. This anxiety extends to space: the middle classes associate urban gandagi (dirtiness) with so-called gande lok (dirty people), often the laboring classes and non-dominant Hindu or Muslim castes. An NGO worker, handling community projects for a real estate developer, explains: "I shouldn't say this but Mohammedans [Muslims] are not very clean; they throw food here and there, do not take trash out of their house properly, and do not bathe." Here waste, and by extension sewage, is tied to specific communities and is even seen as a material and urban-ecological form of the other. These beliefs merge with urban development politics as the case of the sewage treatment plant (STP) exemplifies.

A few miles down from Virgaon's nala, the twists and turns of a narrow, forested road shield a giant STP from curious human eyes. The state-owned plant, cordoned off from the public by a giant chain-link fence, treats sewage from the industrial and residential areas. I visit the plant on a field trip with a group of college students studying urban planning. The sound of water gurgling and the ripe smell of sewage surrounds us as we pull up in a minivan, and the students grimace in disgust. A young man joins us on the site visit. He is an engineer from what he refers to as a "private company" that plans to bid for the contract to manage the plant. Flanked by two small buildings are several round concrete pools. Raised about a meter from the ground, these facultative ponds contain sewage undergoing oxidization. Nozzles spray the sewage-filled water into the air in giant arcs and bubbles, awkwardly mimicking the grace of Versailles fountains as they aerate human waste.

Moving closer to the massive tanks, however, we sense that something is not quite right. The streams of water appear too weak and several fountains look defunct. The young engineer claims that most of the equipment is in disrepair. He informs us that the color of the sewage indicates that oxygenation is not taking place: a healthy plant displays a "chocolatey-brown" color, but this sewage is a strange green-brown. The site supervisor later tells us that the "private company" will probably want the government to repair it before they take over the plant, implying that the company just wants a fast buck and no work.

The large-scale, modernized infrastructure of the STP, languishing and festering in dysfunction while public and private authorities argue over who must 
work to fix it, serves as a metonym for the disarray of Gurgaon. Gurgaon, individuals in construction tell me, grew through the corruption of and collusion between state authorities, developers, and contractors. Examples of regulatory and developmental manipulations narrated range from piecemeal conversions of land use, especially from agricultural to urban, facilitating land financialization through state-led dispossession, and granting exceptions to unauthorized construction projects. Decisions, such as introducing new masterplans to expand the footprint of the urbanizable area into surrounding agrarian or forested land, occur through public-private liaisons. This warping and bending of real estate regulations saw large housing colonies emerge in areas without adequate road, sewer, water, or electrical infrastructure.

Maansinghji, a jovial and charismatic Jat planner in the Haryana Urban Development Authority, has choice words about this form of urban development. Jats agitated for affirmative action in 2016, wanting to be listed as Backward Class in Haryana; they form a majority in Haryana and also dominate the state legislature. Maansinghi is well connected with local political leaders; nevertheless, he is quick to criticize politics. He gives the example of a special economic zone (SEZ) in Gurgaon where government corruption enabled private profiteering and land degradation. According to him, the chief minister of Haryana allocated large tracts of land as a SEZ and awarded it to a specific real estate conglomerate with which he had ties. "With the excuse of the SEZ, the chief minister's aadmis [men] purchased land cheaply, people sold the land because you cannot do anything with land within an SEZ. While the farmers sold at 60 lakh [US\$83,000] per acre, the chief minister and town planners later changed the land use and the cost of the land rose to 4 crores [US\$5,500,000] per acre.” He gesticulates in anger at the dispossession enacted by state officials acting as private entities. "You can say it is a development. . . . You are the private developer, you put the money and got land use changed and made money." According to him, this is profiteering off land and not development: "Did they supply water? Did they build a sewer? . . Only [marking] on the paper [that] this is an ' $\mathrm{R}$ ' zone [residential zone] or this is an 'industry' zone? Is that development?" Maansinghji's critique views the sewage on the street as a symbol of state officials privately profiting from real estate development.

To turn off a main road in Gurgaon is to be met with the heady, all-encompassing smell of wastewater. Sewage spreads across urban village streets, flows down open drains, and emerges in shallow pools; this surreptitious seepage is often accompanied by conversations about raw water, excreta, and urban decay. ${ }^{13}$ The sensoriality of sewage in Gurgaon - potent-smelling and visibly grotesque, felt in 
the slime between one's toes and in the heat that emanates from it - is not only a phenomenology of caste politics but also of political-economic corruption. The presence and visibility of sewage lends a strong sensoriality to behind-closed-doors collusion. It represents a state and a set of construction elites unwilling to do the work of building urban infrastructures. Put another way, excreta are the visceral form of the invisible work of political-economic corruption, land financialization, and the anxieties of caste impurity, a mode through which physical and political corruption becomes visible. The conversion of this waste to value also relies on the confluences of economic and religious impurity, as the next section will depict.

\section{EXTRACTIONS}

In 2012, most new developments and so-called urban villages in Gurgaon did not have a sewage system. New real estate projects had to build their own septic tanks and waste infrastructure. These were to be cleaned and maintained by private contractors instead of governmental agencies. Real estate developers, in their fast-paced construction, often failed to provide adequate septic tanks or to maintain those already built; this led to vast amounts of sewage seeping into drains and open canals. Sewage constitutes the literal waste of real estate economic growth, and without constant maintenance, it leads to loss of real estate's value.

Specific communities of Dalits in India have historically been relegated to sewage work, and this legacy continues through structural systems of poverty and Hindu power: Dalits are read by dominant-caste Hindus as impure. Gurgaon is no exception to caste discrimination. As sewage spreads in Gurgaon, teams of Adivasi (Indigenous) and Dalit workers are hired to manage waste. The preponderance of septic tanks and the shortage of equipment such as pumping trucks mean that sewage workers often physically enter septic tanks to clean them and move sewage with carts or trays. Though the manual scavenging, carrying, and carting of sewage is illegal in India, in reality, the demand for workers to excavate clogged sewers and septic tanks has increased in Gurgaon due to its exponential growth. In 2017, a sewage worker — promised a little under US\$10 to clean a sewer-fainted from the toxic fumes emanating from the tank and fell in. As his two colleagues jumped in to save him, they, too, lost consciousness and died. The incident took the death toll of sewage workers in NCR to fifteen workers in three months (Alam 2017).

Sewage and waste formed important elements of colonial operations, ${ }^{14}$ and this history of dominance continues along caste lines. Sewage workers, sweepers, and cleaners in Gurgaon are treated as the refuse of society while simultaneously 
being called on to labor for it. ${ }^{15}$ Harelal, a migrant manual scavenger and street sweeper, works with a team of "mates" who come from the same village as him. "They treat us like the insects of the gutter," he says of the social discrimination they face. As a Dalit man who sweeps streets and scavenges for a living, earning less than US\$0.50 a day, Harelal is regularly yelled at by dominant-caste individuals for entering their spaces. They treat him as if he belongs in the very nala he cleans, he says. A "casteization of capital" (Shepherd 2019, 66) occurs as the labor of Dalit and Adivasi sewage workers ensure that Gurgaon's waste does not clog its real estate growth. In this process, they immerse their unprotected bodies into the waste and expose themselves to the microbial diseases the sewer carries, as well as to the toxicity of its gas emanations. The cleaning, carting, and care of waste increase real estate value: real estate value is extracted from the health and social standing of sewage workers, ${ }^{16}$ and yet it further denigrates and devalues the labor and care of non-dominant-caste workers.

Tracing the importance of sewage in the real estate industry makes visible the embodied politics underlying the transformation of Gurgaon. Here, political-economic conceptions of corruption exacerbate caste-based violence and worsen labor relations. On the one hand, the labor of Dalit and Adivasi workers manages waste to generate real estate value; on the other hand, public-private collusion produces value through the shirking of infrastructural work and the generation of sewage. Here religious and political-economic understandings of corruption form an interlinked system that furthers urban growth and creates unequal labor and physical risk. This inequality is recognized and critiqued through an embodied politics of the pet.

\section{ACCUMULATION}

The Hindi word for "stomach" is pet (peth), and the stomach connotes survival and sustenance in Indian labor politics. To do fieldwork in construction provides a lesson in the politics of the pet. As Kishwar, a young foreman, explains, work is a way to feed yourself and your family: "If the plant works, we will get fed [pet ko dana milega; literally, the stomach will get grain].” For a foreman and construction worker, the pet is always hungry, and you have to labor to satiate it, whereas a growing pet, or a big belly, symbolizes the opposite. A big pet stands as a historical, political-economic critique: it is the rich, male, dominant-caste trader or landowner - the sahukar (moneylender), malik (landowner), or a Bania (trader caste) — who has a big belly, a belly gained from a life of abundant food and no labor. It is against this historical background that the term khatein (to eat) is often 
used to refer to how a corrupt, rich patriarchy eats money. Here corruption takes both an economic form (eating money or benefiting from the labor of the poor) and a physical form (weight gain). ${ }^{17}$

In 2012, as I moved through Gurgaon, the real estate industry was yielding a wealth of riches. Tower cranes perched on building after building and created an endless horizon of construction work. Farm properties displayed signage for developments to come, and laborers crowded into squares in hopes of gaining an income. The rising property prices turned Gurgaon's landowners into "rural crorepatis [millionaires]." ${ }^{18}$ India, the world's largest consumer of gold (Sreenivasan 2012), shifted to investing in land (Seth 2013), and the discourse attending this shift was evident everywhere. As I moved through the sites and fields of Gurgaon, people gave me investment advice: "Place your money in property and it will bear fruit of gold." "The returns on land investment in India are incredible . . . why would we invest in anything else?" Amar, a Bania real estate executive, describes his company's beginnings amid this fervor for property: "We entered [the market] with a lot of noise. . . In my mind we were the loudest ones and took other investments as competition. Boom — what an appetite!”

As Amar describes, developers in the region (several of whom were Hindu-dominant caste) expressed an insatiable hunger for development, and many indulged in veritable land banquets. Developers bought land parcels, pitched projects, and used money from the sales of one project to buy land for others, often leaving projects incomplete and real estate consumers empty-handed. Such were developer appetites that the majority of prominent real estate firms faced land and consumer litigation in $2018 .^{19}$

Just as private developers were accused of eating their customers' money, so, too, were public officials. Subas, a laborer from the Banjara community, meets me at a construction site in Gurgaon where he works as a beldar (coolie). He describes the day-wage labor and herding through which his landless, tribal community makes a living. He describes road construction schemes in his district that provide laborers with work under the Mahatma Gandhi National Rural Employment Guarantee Act (MGNREGA or NREGA). He complains that it is difficult to work for NREGA because of the bribes the contractors take: "The world these days is useless, everyone just makes money off each other," he says. Workers make negligible amounts in NREGA payments because payments are whittled down as each supervisor in the chain takes a cut. Subas explains, "If at the top $[₹] 300$ is given, then the [people in the] middle will only get 100-100 [₹100 each].” He describes their greed in alimentary terms: "eating, eating [khatein-khatein], they eat [the money]." 
This pilferage results in individuals like Subas, described as Below Poverty Line (BPL), ending up with miniscule amounts. "They give us ₹20-20 a day . . . it is 115 [the official day rate is ₹115] . . . but only ₹20-20 come, everything else is eaten up," he complains.

Khatein-khatein (eating-eating, following the Indian style of emphasis by repeating words) accentuates the degree of severity of eating money, of the systematic accumulation of money earned by the hard labor of the poor. Subas's critique marks a wider distrust of state officials and the wealthy, and it links the politics of eating and ingestion to the politics of state corruption in development. Neelkanth Sir, a planner and Gurgaon resident, echoes Subas's feelings. As he gives me a ride home, he tells me that "because of corruption there is development-definitely write that." He explains, "take an engineer, for example: he keeps drawing work to himself so that he can eat money [paisein kha sakein]." According to Sir, urban development in India will only take place through corruption.

To act in a corrupt manner is to eat unequally; it is to starve the poor and grow wealthy off another's labor. Affluent individuals in this imagination physically imbibe this excess of value and manifest it in their flesh. Mr. Yadav speaks of how his community's riches transform the bodies of Ahir youth: "Let us take health for example: there is no work to do. . . . Now in the village we have city-based illness, like for example heart attacks. They say that it happens to Banias [traders] as they sit around doing nothing, or over-weightness [sic] that happens. We call them the diseases of the rich, and now they have come to everyone, everyone's knees are hurting, everyone is gaining weight." He describes bodily changes: "In the old days women used to be beautiful, now they are fatty-fatty."

Mr. Yadav's words were perhaps intended for me as an overweight woman who comes from a self-defined Bania family, but his use of Bania as an example serves a reminder that some of India's biggest billionaires hail from that group. For many such as Subas, who also asked me why I am so fat, obesity signals an affluent person. As construction workers say, it is only the rich who do not worry about pet bharna (filling one's stomach), bhookhe marna (dying hungry), or the majboori (binding necessity) that brings workers to site.

As the material environment transforms, and as people profit off these transformations, it is said that the metabolisms and physiologies of the rich slowly deteriorate; their flesh becomes morbid from the wealth they have eaten. As Mr. Yadav puts it, the weight of dominant-caste money now manifests in Ahir bodies as they grow wealthy from real estate. This body politic around wealth accumulation even extends to the nation as a whole, as when Prime Minister Narendra Modi refers to 
the economy of bribes and corruption as a bimari (illness), even suggesting "operations" to control it (McDowell 2017). The real estate economy literally grows both the body of the urban region or nation and the bodies of those who profit from it. It causes disease in both.

Fatness or obesity is a social stigma and often blurs gender divisions to render those labeled as fat as immoral (Greenhalgh 2012, 473; Brewis et al. 2017) or as less valuable (Edmonds and Mears 2017, 33). But the size of bodies can also correlate to financial status (Trainer 2017). ${ }^{20}$ In the case of Gurgaon and its agrarian residents, discourses around fatness and eating take social stigmas and turn them into political economic critiques of the state and elite classes. A bulging belly in the Indian context has a long-standing connection with reputation, profit, and power (Solomon 2016, 45), but of relevance here is the rise of this discourse in a transforming ruro-urban region. Mr. Yadav fears for himself and his grandchildren as they move from growing their own crops and milking their own cows to eating in restaurants and at street stalls. As the Ahir staple diet of milk products and millet is replaced by the rich foods of the elite, what threatens to alter the bodies of his community is not a disease-producing external agent but a transformative dominant-caste lifestyle, facilitated by the real estate economy. To develop an area is to eat money, to paraphrase Sir. While the waste of urban development is managed by Dalit and Adivasi individuals, the value of urban development manifests in the bank accounts and corpulence of imagined male Jats, Banias, and Ahirs in Gurgaon. As Vinay Gidwani and Anant Maringanti (2016, 125) write, "the conditions of capitalistic value come to lie in bodies, places, and things that come to be designated at the front end and back end of capitalism.” To grow fat means to manifest the corruptions brought on by the accumulation of value in a real estate market; it is to gain wealth and weight. The weight of eating-eating ties to the stench of corruption that emanates from sewage on Gurgaon streets; both constitute forms of waste-value that reveal unequal accumulations and the dangers of the same. Here, corruption as accumulation critiques caste- and class-based inequity in real estate.

\section{IMBALANCES}

A real estate economy produced through political-economic corruption has thrown life and land out of balance for an agrarian, mobile, caste community like the Ahirs in Gurgaon. The corrupt real estate economy is said to create an internal, invisible corruption that transforms the body and coerces it into wanting and doing unexpected things. This transformative influence, locals argue, stems from the influx of multinational capital and its accompanying ecologies and food: 
I am told that bodies behave differently in a new Gurgaon. Neelkanth Sir is a retired planner who was born and bred in Gurgaon. As a member of both Gurgaon and Ahir planning circles, he has several opinions on the development of the urban region. One of his primary grouses is the presence of Western ways of life and "American" (U.S.) culture in India. India's neoliberal economic restructurings in the 1990s deregulated industries such as banking, pharmaceuticals, and food supply, and with these economic restructurings came North American restaurant chains, food products, home goods, music, and cable television. The central aesthetic and material form of "America" (United States of America as the country representative of multinational capital) was real estate.

In Gurgaon, the rising new malls with Nike stores, the Big Bazaar supermarkets, and the glass office buildings advertising companies such as Tetra Pak, Mercedes, and Dell indexed the omnipresence of European and North American influence in urban expansion. Real estate development spread an aesthetic and material culture imported from the West, in effect producing an idea of "America" through the buildings and infrastructure they built (Dharia 2014). Supposed Americanness and urbanism have come to be linked and manifested in materialities such as architecture, fast food, highways, and jeans. Neelkanth Sir's rants about "America" are therefore connected to developing real estate.

Corruption, he believes, is a U.S. conspiracy. "They are changing us through the food and TV," he says, as he lists popular fast-food chains: "Look at McDonald's and Subway and all the programs on TV." The addictive properties of fast food and cable television have brought about desires that, according to him, did not previously exist in Gurgaon. "You look at my own nephews," he says of the young men in his multigenerational agrarian household: "they are all drinking and smoking. They sit at home and all of them are spoilt." Here unemployment is a condition created by the acquisition of ancestral agrarian lands and their subsequent conversion to real estate, rendering the young men jobless. Sir uses one of his nephews as an example. He got his nephew a job in a local transport company. The nephew worked for a few days, then drank on the job for several consecutive days, and quit work. Sir mediated and had him rehired, but the alcoholism proved too strong. The uncle feels alcoholism has taken hold of all the younger men in the village: "All these boys, they are intoxicated by alcohol [bas sharaab ka nasha hain]."

The transformative urges of an American-influenced, corrupt economy do not stop at a taste for videshi daroo (foreign liquor). These new urges, addictions, and desires also correspond to gendered behavioral changes. Mr. Yadav complains about young women marrying out of the community. Daughters nowadays are 
completely spoiled, he claims, as they follow their hormones and marry whomever they want (thus violating caste and community norms). Critiques of libidinal and hormonal changes are on the rise in Gurgaon. In 2012, a khap panchayat of Haryana declared that chowmein, a street dish of stir-fried noodles, leads to rape. Khap panchayats are governing bodies for villages in North India, who set moral codes of conduct. Known and criticized for a number of laws such as barring intercaste marriage and punishing couples who married within their own village, the khaps recently turned their moral gaze to fast food. The Times of India quoted the khap leader: "To my understanding, consumption of fast food contributes to such incidents. Chowmein leads to hormonal imbalance evoking an urge to indulge in such acts" (Saini 2012).

The comment drew both national outrage and mockery in English-language newspapers and television shows that also referenced the patriarchal attitudes of khap panchayats, but it reflects a widely shared belief that fast food causes hormonal imbalances and changes in physiology and mental state. The comment ties to local conceptions of Ayurveda and humoral understandings of body-food-environment relations (see Raheja 1988; Gupta 2003), and it resonated with many subtle references, among locals and scientific journals alike, to fast food as a disease-causing, imbalance-producing agent, such as talk of the "unnaturalness" of pizza.

But new rhythms are growing apace in Gurgaon and, as Mr. Yadav noted, they do not seem to be in sync. As Gurgaon expands, malls full of fast-food chain restaurants become markers of an urban, middle-class identity in which the very idea of middle-classness and urbanity is consumed through food, movies, and retail spaces (Brosius 2010; Mankekar 2015; T. Srinivas 2018). In a country where practices of consumption and the preparation of food govern hierarchies of caste, fast food and industrial foods can be caste-neutral, thus serving as "an act of imagining citizenship that cuts across social hierarchies" (Baviskar 2018, 5-6). Debates over urges and consumption, then, can also connect to anxieties around the transformation of Western urban cultures, citizenship demographics, gendered behavior, and caste hierarchies in the region.

I am repeatedly told that Haryana is a state that prides itself on its milk products, its bodybuilding, and its army regiments. Good food and health practices in the Ahir (and Jat) communities are tied to exercise in masculine wrestling spaces and healthy eating through food obtained from one's own farmlands and buffalos. A popular saying shows how conceptions of naturalized and un-naturalized food-bodies are produced in the region: "Yeh hai hamara Haryana jithe doodhi 
dahi ka khana" (this is our Haryana where they eat milk and yoghurt). Indeed, moving through Gurgaon's urban villages means seeing milk-producing buffalos tethered to the entrances of houses in a state that believes in muscular strength and health through milk. When buffalo milk and kachri chutney (made from a local melon) compete with burgers and pizza, it seems little wonder that chowmein and other fast foods begin to represent the threat of moral degradation, even when eaten with relish. Malls, on the other hand, stand in opposition to the adjacent mandis (local markets), and apartment complexes to the rural dhanis (homes in fields): here, localized conceptions of Ayurveda and agricultural humors feed a critique of the unevenness of humors and hormones brought about by Western urbanization.

Changing desire and urges connect a real estate and urban development economy to hormonal adjustments and balances in the body. This nexus builds on urban metabolic thinking that understands urban areas as comprising metabolic systems, the dysfunction of which results in clogging, arrhythmia, and decay. The discourse around bodies in Gurgaon operates on the belief that the metabolism of the body transforms in parallel with the urban development of the region. The foods and behaviors of a U.S.-influenced economy, embraced by non-dominant-caste communities and young women alike, prove toxic and dangerous: they alter our behavior and produce alien urges, and the body will not listen to the brain as new economies invade it. Corruption, then, demonstrates not only an inequity of labor, accumulation, and physical risk but also the worry of new economies bringing caste mobilities and the transformation of hetero-patriarchal relations. Corruption in this context indexes the disruption of existing social orders.

Mr. Yadav insists that the solution lies in moving from sukh to anand. Both sukh and anand are terms for happiness, yet he clarifies that sukh is external, while anand comes from inside. Anand represents the spiritual relationship of balance, but sukh describes momentary and monetary satisfaction. A discourse of finding anand circulates in the villages and lower middle-class spaces of NCR. Anand as equilibrium, however, is a historic concept and ties to conceptions of substances in species and the need for equilibrium within them (Daniel 1987, 6). Anand, Mr. Yadav explains, means to find balance and happiness from within rather than from the outside. External happiness, for those who believe in finding anand, proves illusory and perennially unfulfilling.

This pursuit of happiness as an internal balance is revealing as a critique of contemporary times. As a speculative and consumptive economy spurs speculation of peril and dangers, bodies and urban ecologies are recognized as out of sync. 
Rhythms and balances form the metaphors for healing both cities and selves, for re-creating an erased natural ecology and its accompanying humoral balance, and for assuaging the embodied corruptions enabled by transforming urban ecologies.

\section{EMBODIED URBANISMS}

Eating, digesting, and excreting together highlight how a discourse of corruption as a physiological and political-economic phenomenon critiques real estate development in Gurgaon. Corruption, a popular unit of social analysis in India, focuses on either the corrupt state or caste-based politics. Scholars who work on one have tended to pay less attention to the other; though the two threads share a moral lens, they differ in their focus, with the former highlighting capital and government and the latter attending to social discrimination. As a result, the ways in which these two forms of corruption mix to maintain power are occluded. State corruption, understood as the "misuse of public authority for private gain," includes commercial bribery or the crosscutting of codes (Gupta 2012, 79). Not only is corruption a way in which the Indian state is "discursively constituted" (Parry 2000; Gupta 2012, 78; Jauregui 2014); it also proves integral to the ways in which citizenship is forged (Anjaria 2011). While these authors are exemplary in their analyses of everyday politics and politicking, they neglect phenomenological (bodily, sensory, and material) and embodied experience, as well as the intimate and immersive experience of corruption felt deep inside the body and gut. Literature on caste, by contrast, demonstrates the phenomenological experiences of social exclusion, discrimination, and exploitation that tie corruption to bodily fears, discriminatory practices, and extreme violence. Authors describe how the very presence of Dalit and Adivasi individuals is thought of as contaminating or corrupting to dominant-caste communities, resulting in a hypervigilance of and control over the birthing fluids, bodies, blood, sweat, and spittle of Dalits (Ambedkar 2014). Conversely, we might also read sensoriality and phenomenology as a source of Dalit power: "Sensorial Dalit expression," Yengde (2019, introduction) writes, "is an experience of revelation of the person and the personal."

If like Yengde (2019) we see sensoriality as power, as a mode through which to articulate our voice and claim space in the world, then the imaginations, critiques, and experiences of body politics in Gurgaon constitute a battle over power in urban real estate economies. The history of caste-based corruption draws a connection between physiological metabolisms and urban metabolisms; it enables corruption talk to manifest the anxieties and injustices of changing labor patterns, material accumulation, and caste, class, and gender mobility. Corruption allows 
us to tie body politics to the economy in ways that foreground labor and capital; corruption entangles labor politics with talk about wealth, weight, laziness, desire, danger, and discrimination. Local understandings of urban metabolisms are deployed as critiques of social change and real estate economies: corruption opens ways of speaking about embodied urban ecologies. It allows us to read the real estate economy as a physical and economic corrupter, rather than as an aberration (Anjaria 2016, 61) or as wholly negative (Gupta 2012), but as something both dangerous and desirable, perverted and pleasurable.

\begin{abstract}
This article studies metabolic systems of food, body, and waste within the urban development politics of the city of Gurgaon (now Gurugram) in India's National Capital Region. I link rapid urban transformation within the region, the labor required to produce it, and the speculative real estate economy that governs it to the phenomenology of body politics in the region. In particular, I examine corruption as both a political-economic and a physical, caste-based narrative to argue that corruption connects embodiment and urban development ecologies to each other. This allows corruption discourses in Gurgaon to form a critique of real estate economies; changing urban environments are felt and critiqued through body politics and experienced at once as a peril and a pleasure. This work is based on fifteen months of ethnographic research in the construction industry in NCR involving members across the production chain of real estate, including landowners, investment bankers, developers, engineers, architects, foremen, and laborers. [construction; labor; corruption; urban metabolism; body]
\end{abstract}

\title{
NOTES
}

Acknowledgments This article received feedback from the Political Ecology Working Group at Harvard University, Ekin Kurtic, Dilan Yildirim, Ajantha Subramanian, Nicolas Sternsdorff-Cisterna, Elizabeth Roberts, Nishita Trisal, Steven Caton, Jared McCormick, Nancy Khalil, Veronika Kusumaryati, Ramyar Rossoukh, and Brad Weiss. It was copyedited by Philip Sayers. The research was supported by the Wenner-Gren Foundation, the Foundation for Urban and Regional Studies, the Radcliffe Institute for Advanced Study at Harvard University, the Lakshmi Mittal South Asia Institute and the Anthropology Department at Harvard University, the Cora Du Bois Charitable Trust, and the Rhode Island School of Design. Thank you to the editors of Cultural Anthropology, the five anonymous reviewers, Jessica Lockrem, and Petra Dreiser for their time, comments, and edits. Names of people and places have been changed to protect privacy.

1. This reading challenges the integrity and individualism of the human body (Chen 2012, 209 ) and bursts "open categories of organism, individual, and body to acknowledge a shared, entangling, and extensive condition of being with capitalism and its racist colonial manifestations" (Murphy 2017). The body is as an important "scalar intertext" (Agard-Jones 2013, 184). The relationship between the body and its surroundings can be read as a "situated, absorptive interface" (Solomon 2016, 9). Nicholas Shapiro (2015, 
370) refers to sensuous and epistemological apprehension as "bodily knowledge"; this relies on "visceral and indeterminate sensorial facilities" (Shapiro 2015, 375).

2. Eric Swyngedouw (2006) thinks of the city as a cyborg, part human, part mechanic, that forms its own living and thriving entity. Harris Solomon $(2016,9)$ encourages us to adopt metabolism as a "visceral and political interface" between bodies and surroundings. I interpret metabolism as not only a political interface but as an infrastructural, historical, and political entanglement (Haraway 2016) that embeds and actively produces difference and inequality.

3. Waste forms part of a "circulatory sociality" that produces an intimate relationship with the environment and each other (Watanabe 2015, 7). Urban political economy owes a debt to Marx, whose interest in metabolism and nature formed the foundation for his theory of labor. "Marx employed the notion of metabolism to conceptualize two processes . . . : the production of labor power through the exchange of energy between bodies and the environment, and the emergence of an ecological crisis under capitalism" (Zhang 2020, 82). The metabolic rift emerges as a lively debate to examine the historical, social, and ecological ruptures produced by transforming agrarian and urban operations (see Wittman 2009; Schneider and McMichael 2010; Moore 2011). Corruption talk in Gurgaon constructs emic ruro-urban conceptions of metabolic rifts challenging top-down examinations that divide the agrarian from the urban, reminding us that it is imperative not to take metabolism as a given (Solomon 2016, 72-73).

4. Often this is critiqued through scatological humor (Weston 2017, 171). Obscenity and grotesqueness form an integral part of the stylistics of power, and laughing drains officialdom of meaning (Mbembe 1992, 14, 25).

5. The Hindi word for pollution (padushan) does not connect to religion but is used for environmental pollution; impurity (apavitra), inauspiciousness (ashubh), and falling from religion (dharma bhrashtra) are used instead.

6. Specific Dalit communities were historically assigned to "polluting operations such as dealing with human excreta and animal carcasses” (Baviskar 2018, 5; see also Valmiki 2003). Caste is relevant to the contemporary processing of waste, as it is Dalits in urban areas who are relegated to the task (Gidwani 2015). It is important, however, not to occupationally stereotype (Rawat 2011,11) and to examine the intersectionality of class and caste (Subramanian 2019, 11).

7. This is a rough estimate based on rural areas converted to urban in development plans released in the years between 2007 and 2012.

8. Real estate in Gurgaon took on a speculative form. Speculation as a component of formal finance and banking has salience in India (Sunder Rajan 2005, 19). Speculation, financialization, and neoliberal reforms are inseparable (Peterson 2014, 179) and act through localized individuals, legalities, networks, and spaces, while simultaneously negotiating international ones (e.g., Sassen 2001; Ho 2005; Searle 2016; Stout 2016).

9. A movement led by Anna Hazare challenged the framing of a government of India anti-corruption bill - the Lokpal and Lokayutkta Bill. The bill sought to create a tribunal that would try cases of political corruption. Real estate figured prominently in these protests.

10. Nomenclatures for caste communities vary in India and people self-identify. Terms include political self-definition such as Dalit, DalitBahujan, and Adivasi. Government umbrella categories include Scheduled Castes or Backward Classes, and specific communities that fall under these, such as Ahir, Lohar, and Banjara, are also used.

11. For example, "the high-end DLF Icon went from ₹2,800 per square foot in 2005 to $₹ 15,000$ per square foot in January 2012; a more affordable project, Orchid Petals, went from ₹1,800 per square foot to ₹8,750” (Donthi 2013).

12. Strict social protocols around the making and serving of food (Appadurai 1981) have aggressive consequences for non-dominant-caste individuals who violate them (Valmiki 2003). Everything from sex to menses, childbirth, and the sowing of seeds have protocols to avoid the mixing of inauspicious fluids and bodily impurity (Raheja 1988). As Gloria Goodwin Raheja $(1988,59)$ notes, there are several intersecting systems of inaus- 
piciousness at play, but caste pays a central role in the creation or mitigation of impurity through substance.

13. Kath Weston (2017, 152-55, 168-9), Veena Talwar Oldenberg (2018, 108, 192), and Shubhra Gururani (2017) list sewage and waste discourses in the region.

14. Dirt, Mary Douglas $(2002,9)$ writes, is a historically coded and socially constructed relative category. Sewage licenses colonial and postcolonial practices of social control (of the racialized and colonized poor) through the dialectic between disease and hygiene. Excrement divides individuals into grotesque and sublime (Anderson 1995, 650); "it was and is a mode of exercising white superiority and expertise" (Patterson 2009, 553). Shit becomes the opposite of that which is beautiful, civilized, and respectable (Geest 1998, 9), where "those handling waste . . . are themselves thought of as "refuse" (Fredericks 2014, 4). Garbage on Indian streets enacts a struggle over colonial and postcolonial modernity (Chakrabarty 1991, 29). Waste produces intertwined dualities such as local-modern, public-private, and urban-rural in Indian urbanism (Kaviraj 1997; Gururani 2017). "Focusing on waste draws attention to jettisoned histories of disregard and violent erasure (Huang 2017, 103; see also Gordillo 2011, 143; Chalfin 2014, 94), and congeals "new kinds of workers and industrial infrastructures" together (Blanchette 2019, 83). Waste and sanitation discourse in India acquired a public space (Chakrabarty 1991) and planning register (Glover 2008, 46, 131-35) that continues today with international development focusing its sanitation agenda on India (Coffey and Spears 2017; Irani 2019, 141-71). Tracing waste infrastructures, especially their networks, movements, dysfunctions (Graham 2010), materialities (Anand 2017), and politics (Björkman 2015) reveals critiques of development.

15. A 2016 analysis of the National Crime Records Bureau (NCRB) reported 40,801 atrocities committed against Dalits. Highest among categories of crimes were rapes of Dalit women (Saaliq and Bose n.d.). These numbers are likely conservative, as the NCRB is accused of suppressing minority crime data (Schultz et al. 2019).

16. As Vinay Gidwani and Anant Maringanti $(2016,115)$ write, "the production of value within the capitalist space economy would be impossible without the work of waste management."

17. The metaphor of corruption as "eating" is common to many countries. Jennifer Hasty (2005, 282), for example, speaks of corporeal metaphors to describe state corruption in Ghana including eating (corruption), vomiting (anticorruption), and the state constituting edible resources.

18. This was a differential gain of wealth depending on when you sold your land and how much you saved. There are also communities who did not own land and who were economically disadvantaged in this land price boom.

19. In 2018 developers such as Jaypee, Unitech, Amrapali, Emaar, DSK Group, PACL, Supertech, Ultratech, Ats Infrastructure, Omaxe, DLF, M3M, Vatika, and Logix Groups had litigation against them (Ankit Sharma 2018).

20. Fat bodies are often viewed as disgusting or risky and tied to immorality (Brewis et al. 2017, 259), but these readings vary according to context (Brewis and Wutich 2014); the meaning of fat shifts historically and cross-culturally (Kwan and Graves 2013, 4).

\section{REFERENCES}

Agard-Jones, Vanessa

2013 "Bodies in the System." Small Axe 17, no. 3: 182-92. https://doi.org/10.1215/ 07990537-2378991.

Alam, Shafaque

2017 "Three Men Die Inside Noida Sewer, Toll in NCR 15 since July." Times of India, September 22. https://timesofindia.indiatimes.com/city/noida/three-men-dieinside-noida-sewer-toll-in-ncr-15-since-july/articleshow/60787520.cms.

Ambedkar, B. R.

2014 Annihilation of Caste: The Annotated Critical Edition. New Delhi: Navayana. 
Anand, Nikhil

2017 Hydraulic City: Water and the Infrastructures of Citizenship in Mumbai. Durham, N.C.: Duke University Press.

Anderson, Warwick

1995 "Excremental Colonialism: Public Health and the Poetics of Pollution." Critical Inquiry 21, no. 3: 640-69. https://doi.org/10.1086/448767.

Anjaria, Jonathan Shapiro

2011 "Ordinary States: Everyday Corruption and the Politics of Space in Mumbai." American Ethnologist 38, no. 1: 58-72. https://doi.org/10.1111/j.1548-1425.2010. 01292.x.

2016 The Slow Boil: Street Food, Rights and Public Space in Mumbai. Stanford, Calif.: Stanford University Press.

Appadurai, Arjun

1981 "Gastro-politics in Hindu South Asia." American Ethnologist 8, no. 3: 494-511. https://doi.org/10.1525/ae.1981.8.3.02a00050.

Baviskar, Amita

2018 "Consumer Citizenship: Instant Noodles in India." Gastronomica 18, no. 2: 1-10. https://doi.org/10.1525/gfc.2018.18.2.1.

Björkman, Lisa

2015 Pipe Politics, Contested Waters: Embedded Infrastructures of Millennial Mumbai. Durham, N.C.: Duke University Press.

Blanchette, Alex

2019 "Living Waste and the Labor of Toxic Health on American Factory Farms." Medical Anthropology Quarterly 33, no. 1: 80-100. https://doi.org/10.1111/maq.12491.

Brewis, Alexandra, Sarah Trainer, SeungYong Han, and Amber Wutich

2017 "Publically Misfitting: Extreme Weight and the Everyday Production and Reinforcement of Felt Stigma.” Medical Anthropology Quarterly 31, no. 2: 257-76. https://doi.org/10.1111/maq.12309.

Brewis, Alexandra A., and Amber Wutich

2014 "A World of Suffering? Biocultural Approaches to Fat Stigma in the Global Contexts of the Obesity Epidemic." Annals of Anthropological Practice 38, no. 2: 269-83. https://doi.org/10.1111/napa.12056.

Brosius, Christiane

2010 India's Middle Class: New Forms of Urban Leisure, Consumption and Prosperity. New Delhi: Routledge.

Chakrabarty, Dipesh

1991 "Open Space/Public Place: Garbage, Modernity and India." South Asia 14, no. 1:

Chalfin, Brenda 15-31. https://doi.org/10.1080/00856409108723146.

2014 "Public Things, Excremental Politics, and the Infrastructure of Bare Life in Ghana's City of Tema." American Ethnologist 41, no. 1: 92-109. https://doi.

Chen, Mel Y. org/10.1111/amet.12062.

2012 Animacies: Biopolitics, Racial Mattering, and Queer Affect. Durham, N.C.: Duke University Press.

Coffey, Diane, and Dean Spears

2017 Where India Goes: Abandoned Toilets, Stunted Development and the Costs of Caste. New Delhi: HarperCollins.

Daniel, E. Valentine

1987 Fluid Signs: Being a Person the Tamil Way. Berkeley: University of California Press.

Denis, Eric, and Marie-Hélène Zérah, eds.

2017 Subaltern Urbanisation in India: An Introduction to the Dynamics of Ordinary Towns. New Delhi: Springer Nature India. 
Dharia, Namita

2014 "Artifacts and Artifices of the Global: Practices of US Architects in India's National Capital Region.” Global South 8, no. 2: 49-64. https://doi.org/10.2979/

Donthi, Praveen globalsouth.8.2.49.

2013 "The Road to Gurgaon: How Brokers of Land and Power Built the Millennial City.” Caravan, December 31. http://www.caravanmagazine.in/reportage/road-

Douglas, Mary gurgaon?page $=0,1$.

2002 Purity and Danger: An Analysis of Concepts of Pollution and Taboo. New York: Routledge Classics.

Edmonds, Alexander, and Ashley Mears

2017 "Managing Body Capital in the Fields of Labor, Sex, and Health." In Fat Planet: Obesity, Culture, and Symbolic Body Capital, edited by Eileen P. Anderson-Fye and Alexandra Brewis, 33-48. Santa Fe, N.Mex: School for Advanced Research Press.

Fredericks, Rosalind

2014 "Vital Infrastructures of Trash in Dakar." Comparative Studies of South Asia, Africa and the Middle East 34, no. 3: 532-48. https://doi.org/10.1215/1089201X-2826085.

Geest, Sjaak Van Der

1998 "Akan Shit: Getting Rid of Dirt in Ghana." Anthropology Today 14, no. 3: 8-12. https://doi.org/10.2307/2783049.

Gidwani, Vinay

2015 “The Work of Waste: Inside India's Infra-Economy." Transactions of the Institute of British Geographers 40, no. 4: 575-95. https://doi.org/10.1111/tran.12094.

Gidwani, Vinay, and Anant Maringanti

2016 "The Waste-Value Dialectic: Lumpen Urbanization in Contemporary India." Comparative Studies of South Asia, Africa and the Middle East 36, no. 1: 112-33. https://doi.org/10.1215/1089201x-3482159.

Glover, William J.

2008 Making Lahore Modern: Constructing and Imagining a Colonial City. Minneapolis: University of Minnesota Press.

Goldman, Michael

2011 "Speculative Urbanism and the Making of the Next World City." International Journal of Urban and Regional Research 35, no. 3: 555-81. https://doi.org/10.1111/ j.1468-2427.2010.01001.x.

Gordillo, Gastón

2011 "Ships Stranded in the Forest: Debris of Progress on a Phantom River." Current

Graham, Stephen Anthropology 52, no. 2: 141-67. https://doi.org/10.1086/658909.

2010 Disrupted Cities: When Infrastructure Fails. New York: Routledge.

Greenhalgh, Susan

2012 "Weighty Subjects: The Biopolitics of the U.S. War on Fat." American Ethnologist Gupta, Akhil 39, no. 3: 471-87. https://doi.org/10.1111/j.1548-1425.2012.01375.x.

2003 Postcolonial Developments: Agriculture in the Making of Modern India. Durham, N.C.: Duke University Press. Originally published in 1998.

2012 Red Tape: Bureaucracy, Structural Violence, and Poverty in India. Durham, N.C.: Duke University Press.

Gururani, Shubhra

2017 “'Designed to fail': Techno-politics of Disavowal and Disdain in an Urbanising Frontier." Economic and Political Weekly 52, no. 34: 38-46. https://www.epw.in/ journal/2017/34/special-articles/\%E2\%80\%98designed-fail\%E2\%80\%99.html.

Haraway, Donna J.

2016 Staying with the Trouble: Making Kin in the Chthulucene. Durham, N.C.: Duke University Press. 
Hasty, Jennifer

2005 "The Pleasures of Corruption: Desire and Discipline in Ghanaian Political Culture.” Cultural Anthropology 20, no. 2: 271-301. https://doi.org/10.1525/ can.2005.20.2.271.

Herzfeld, Michael

1992 The Social Production of Indifference. Chicago: University of Chicago Press.

Ho, Karen

2005 "Situating Global Capitalisms: A View from Wall Street Investment Banks." Cultural Huang, Michelle N. Anthropology 20, no. 1: 68-96. https://doi.org/10.1525/can.2005.20.1.068.

2017 "Ecologies of Entanglement in the Great Pacific Garbage Patch.” Journal of Asian American Studies 20, no. 1: 95-117. https://doi.org/10.1353/jaas.2017.0006.

Irani, Lilly

2019 Chasing Innovation: Making Entrepreneurial Citizens in Modern India. Princeton, N.J.: Princeton University Press.

Jauregui, Beatrice

2014 "Provisional Agency in India: Jugaad and Legitimation of Corruption." American Ethnologist 41, no. 1: 76-91. https://doi.org/10.1111/amet.12061.

Kaviraj, Sudipta.

1997 "Filth and the Public Sphere: Concepts and Practices about Space in Calcutta." Public Culture 10, no. 1: 83-113. https://doi.org/10.1215/08992363-10-1-83.

Kumar, K. P. Narayana, and Udit Misra

2012 “Gurgaon: How Not to Build a City." Forbes India, August 2. https://www. forbesindia.com/article/real-issue/gurgaon-how-not-to-build-a-city/33444/1.

Kwan, Samantha, and Jennifer Graves

2013 Framing Fat: Competing Constructions in Contemporary Culture. New Brunswick, N.J.: Rutgers University Press.

Lee, Joel

2017 "Odor and Order: How Caste Is Inscribed in Space and Sensoria." Comparative Studies of South Asia, Africa and the Middle East 37, no. 3: 470-90. https://doi. org/10.1215/1089201x-4279188.

Mankekar, Purnima

2015 Unsettling India: Affect, Temporality, Transnationality. Durham, N.C.: Duke University Press.

Mbembe, Achille

1992 "Provisional Notes on the Postcolony." Africa: Journal of the International African Institute 62, no. 1: 3-37. https://doi.org/10.2307/1160062.

McDowell, Andrew

2017 "(De)monetizing Health: Cash, Credit, and the Commoditization of Indian Healthcare." Hot Spots, Fieldsights, September 27. https://culanth.org/fieldsights/

Moore, Jason W. demonetizing-health-cash-credit-and-the-commoditization-of-indian-healthcare.

2011 "Transcending the Metabolic Rift: A Theory of Crises in the Capitalist WorldEcology." Journal of Peasant Studies 38, no. 1: 1-46. https://doi.org/10.1080/0306 6150.2010.538579.

Murphy, Michelle

2017 “Alterlife and Decolonial Chemical Relations." Cultural Anthropology 32, no. 4: 494-503. https://doi.org/10.14506/ca32.4.02.

Oldenberg, Veena Talwar

2018 Gurgaon: From Mythic Village to Millennium City. New Delhi: HarperCollins.

Pardo, Italo

2018 "Corrupt, Abusive, and Legal: Italian Breaches of the Democratic Contract." Current Anthropology 59, no. S18: S60-S71. https://doi.org/10.1086/695804. 
Parry, Jonathan

2000 “The 'Crisis of Corruption' and 'The Idea of India': A Worm's-Eye View.” In Morals of Legitimacy: Between Agency and the System, edited by Italo Pardo, 27-55. New

Patterson, Andrea York: Berghahn Books.

2009 "Germs and Jim Crow: The Impact of Microbiology on Public Health Policies in Progressive Era American South." Journal of the History of Biology 42, no. 3:

Peterson, Kristin 529-59. https://doi.org/10.1007/s10739-008-9164-x.

2014 Speculative Markets: Drug Circuits and Derivative Life in Nigeria. Durham, N.C.: Duke University Press.

Rademacher, Anne, and K. Sivaramakrishnan, eds.

2013 Ecologies of Urbanism in India: Metropolitan Civility and Sustainability. Hong Kong: University of Hong Kong Press.

Raheja, Gloria Goodwin

1988 The Poison in the Gift: Ritual, Prestation, and the Dominant Caste in a North Indian Village. Chicago: University of Chicago Press.

Rawat, Ramnarayan S.

2011 Reconsidering Untouchability: Chamars and Dalit History in North India. Bloomington: Indiana University Press.

Saaliq, Sheikh, and Adrija Bose

n.d. "Documenting Violence against Dalits: One Assault at a Time." News18. Accessed October 16, 2020. https://www.news18.com/news/immersive/documentingviolence-against-dalits-one-assault-at-a-time.html.

Saini, Manveer

2012 "Haryana Khap Blames Consumption of Chowmein for Rapes." Times of India, October 16. http://timesofindia.indiatimes.com/india/Haryana-khap-blamesconsumption-of-chowmeinfor-rapes/articleshow/16829882.cms.

Sassen, Saskia

2001 The Global City: New York, London, Tokyo. Princeton, N.J.: Princeton University Press.

Schneider, Mindi, and Philip McMichael

2010 "Deepening, and Repairing, the Metabolic Rift." Journal of Peasant Studies 37, no. 3: 461-84. https://doi.org/10.1080/03066150.2010.494371.

Schultz, Kai, Suhasini Raj, Jeffrey Gettleman, and Hari Kumar

2019 "In India, Release of Hate Crime Data Depends on Who the Haters Are." New York Times, October 24. https://www.nytimes.com/2019/10/24/world/asia/indiamodi-hindu-violence.html.

Searle, Llerena Guiu

2016 Landscapes of Accumulation: Real Estate and the Neoliberal Imagination in Contemporary India. Chicago: University of Chicago Press.

Seth, Shivom

2013 “Indian Farmers Shun Volatile Gold, Buy Land Instead.” Moneyweb, September 5. https://www.moneyweb.co.za/archive/indian-farmers-shun-volatile-gold-buyland-instead.

Shapiro, Nicholas

2015 "Attuning to the Chemosphere: Domestic Formaldehyde, Bodily Reasoning, and the Chemical Sublime." Cultural Anthropology 30, no. 3: 368-93. https://doi.

Sharma, Ankit $\operatorname{org} / 10.14506 / \mathrm{ca} 30.3 .02$.

2018 “YearEnder: Cases That Shook Indian Real Estate in 2018." Economic Times Realty, December 31. https://realty.economictimes.indiatimes.com/news/industry/ yearender-cases-that-shook-indianreal-estate-in-2018/67288294. 
Sharma, Aradhana

2018 "New Brooms and Old: Sweeping Up Corruption in India, One Law at a Time." Current Anthropology 59, no. S18: S72-S82. https://doi.org/10.1086/696070.

Shepherd, Kancha Ilaiah

2019 Why I Am Not a Hindu: A Sudra Critique of Hindutva Philosophy, Culture and Political Economy. New Delhi: Sage.

Smart, Alan

2018 "The Unbearable Discretion of Street-Level Bureaucrats: Corruption and Collusion in Hong Kong." Current Anthropology 59, no. S18: S37-47. https://doi.

Solomon, Harris org/10.1086/695694.

2016 Metabolic Living: Food, Fat, and the Absorption of Illness in India. Durham, N.C.: Duke University Press.

Sreenivasan, T. P.

2012 "In Gold's Own Country." New York Times, December 24. http://india. blogs.nytimes.com/2012/12/24/kerala-golds-owncountry/?_php=true\&_

Srinivas, M. N. type $=$ blogs $\& \_p h p=$ true\&_type $=$ blogs $\& \_r=1$.

1959 "The Dominant Caste in Rampura." American Anthropologist 61, no. 1: 1-16. https://doi.org/10.1525/aa.1959.61.1.02a00030.

Srinivas, Tulasi

2018 The Cow in the Elevator: An Anthropology of Wonder. Durham, N.C.: Duke University Press.

Stout, Noelle

2016 "Petitioning a Giant: Debt, Reciprocity, and Mortgage Modification in the Sacramento Valley." American Ethnologist 43, no. 1: 158-71. https://doi. org/10.1111/amet.12270.

Subramanian, Ajantha

2019 The Caste of Merit: Engineering Education in India. Cambridge, Mass.: Harvard University Press.

Sunder Rajan, Kaushik

2005 "Subjects of Speculation: Emergent Life Sciences and Market Logics in the United States and India." American Anthropologist 107, no. 1: 19-30. https://doi.

Swyngedouw, Eric org/10.1525/aa.2005.107.1.019.

2006 "Metabolic Urbanization: The Making of Cyborg Cities." In In The Nature of Cities: Urban Political Ecology and the Politics of Urban Metabolism, edited by Nik Heynen, Maria Kaika, Erik Swyngedouw, 21-40. New York: Routledge.

Trainer, Sarah

2017 "Glocalizing Beauty: Weight and Body Image in the New Middle East." In Fat Planet: Obesity, Culture, and Symbolic Body Capital, edited by Eileen P. Anderson-Fye and Alexandra Brewis, 171-92. Santa Fe, N.Mex: School for Advanced Research Press.

USGS (U.S. Geological Survey)

2016 "EarthView-New Delhi among Fastest Growing Urban Areas in the World." U.S. Geological Survey website, July 1. https://www.usgs.gov/news/earthview-new-

Valmiki, Omprakash delhi-among-fastest-growing-urban-areas-world.

2003 Joothan: An Untouchable's Life. Translated by Arun Prabha Mukherjee. New York: Columbia University Press.

Watanabe, Chika

2015 "Waste, Incorporated." Gastronomica 15, no. 4: 6-13. https://doi.org/10.1525/ gfc.2015.15.4.6. 
Weston, Kath

2017 Animate Planet: Making Visceral Sense of Living in a High-Tech Ecologically Damaged World. Durham, N.C.: Duke University Press.

Wittman, Hannah

2009 "Reworking the Metabolic Rift: La Vía Campesina, Agrarian Citizenship, and Food Sovereignty." Journal of Peasant Studies 36, no. 4: 805-26. https://doi.

Yengde, Suraj org/10.1080/03066150903353991.

2019 Caste Matters. New York: Penguin Books. Kindle Edition.

Zhang, Amy

2020 "Circularity and Enclosures: Metabolizing Waste with the Black Soldier Fly." Cultural Anthropology 35, no. 1: 74-103. https://doi.org/10.14506/ca35.1.08. 